OPEN ACCESS

Citation: da Costa-Lima J.L., de Oliveira Chagas E.C. (2021) Typification and synonymy of the Atlantic Forest endemic species Napeanthus primulifolius (Gesneriaceae). Webbia. Journal of Plant Taxonomy and Geography 76(1): 89-95. doi: 10.36253/jopt-10377

Received: January 25, 2021

Accepted: February 13, 2021

Published: April 27, 2021

Copyright: @2021 da Costa-LimaJ.L., de Oliveira Chagas E.C. This is an open access, peer-reviewed article published by Firenze University Press (http:// www.fupress.com/webbia) and distributed under the terms of the Creative Commons Attribution License, which permits unrestricted use, distribution, and reproduction in any medium, provided the original author and source are credited.

Data Availability Statement: All relevant data are within the paper and its Supporting Information files.

Competing Interests: The Author(s) declare(s) no conflict of interest.

Editor: Riccardo M. Baldini

ORCID

JLC-L: https://orcid.org/0000-00022967-5322

ECOC: https://orcid.org/0000-00018138-5691

\section{Typification and synonymy of the Atlantic Forest endemic species Napeanthus primulifolius (Gesneriaceae)}

\author{
James lucas da Costa-Lima*, Earl Celestino de Oliveira Chagas \\ Herbário HUEFS, Universidade Estadual de Feira de Santana, Feira de Santana, Bahia, Brazil \\ ${ }^{*}$ Corresponding author. E-mail: jimcostalima@yahoo.com.br
}

\begin{abstract}
During the nomenclatural revision of Acanthaceae names described by Friar J.M.C. Vellozo in his Florae fluminensis, we realized that Pedicularis acaulis Vell. was conspecific with Napeanthus primulifolius (Gesneriaceae), a Brazilian Atlantic Forest endemic species. This study presents the complete and updated synonymy of $N$. primulifolius, including two new synonyms: Pedicularis acaulis and Oreocharis notha C.B.Clarke. We also propose a lectotype for N. primulifolius based on G.Raddi's specimens and $P$. acaulis based on Vellozo's original plate.
\end{abstract}

Keywords: Florae fluminensis, Giuseppe Raddi, historical plant collections, Vellozo.

\section{INTRODUCTION}

Napeanthus Gardner is a Neotropical genus of Gesneriaceae comprising 20 species (and possibly another ten undescribed ones) occurring in tropical rainforests of Central and South America (Leeuwenberg 1958; Weber 2004; Wiehler 1983). The genus shows a conspicuous number of species confined to the Andean foothills (Bolivia, Colombia, Peru, and Venezuela) and the Guiana Shield (Suriname, Guyana, French Guiana, and northern Brazil), besides two disjunct species in the Atlantic Forest of eastern Brazil (based on Leeuwenberg 1958; 1971; Skog 1974; Feuillet and Skog 2002). Napeanthus had already been previously pointed out by Leeuwenberg (1958) as a unique genus among New World Gesneriaceae, later allocated by Wiehler (1983) in its own tribe, Napeantheae Wiehler. Recently molecular phylogenetic studies support this monogeneric tribe as the first diverging lineage in the subfamily Gesnerioideae Burnett, recovered as sister to clade consisting of tribes Beslerieae Bartling \& Wendl.f. + Titanotricheae Yamaz. ex W.T.Wang (Smith 2000; Möller and Clark 2013; Luna et al. 2019; Ogutcen et al. 2021). Species of Napeanthus are distinguished from other New World Gesneriaceae by being rosette herbs, generally acaulescent, with grouped stomata (in islands), calyx generally accrescent in fruit, stamens typically 4 (plus a staminodium), nectary absent, and dry capsules with loculicidal or septicidal dehiscence (Leeuwenberg 1958; Wiehler 1983; Weber 2004). 
Napeanthus was described by Gardner (1843) to accommodate a peculiar species from the Atlantic Forest of Serra dos Órgãos, in the State of Rio de Janeiro, Brazil, named N. brasiliensis Gardner. Nonetheless, an obscure species described in Oxalidaceae ca. 20 years before Napeanthus by Raddi (1820), Oxalis primulifolia Raddi [as "primulaefolia"], was pointed out by Sandwith (1956) as conspecific with $N$. brasiliensis, being the accepted and correct name for this species. Alongside $N$. reitzii (L.B.Sm.) Burtt ex Leeuwenb., they are the only known species of Napeanthus distributed in the Brazilian Atlantic Forest (Leeuwenberg 1958; Chautems 1991; Chautems 2003; Hinoshita et al. 2018).

During the preparation of the nomenclatural revision of Acanthaceae names described by Vellozo (1829, 1831) in his "Florae fluminensis," we detected that one of the names under Pedicularis L. (genus in which Vellozo described some Acanthaceae, following the Linnean arrangement "Didynamia, Angiospermia") did not match any taxa of this family known to Brazil. This intriguing species (i.e., Pedicularis acaulis Vell.) represented a species of Napeanthus (i.e., N. primulifolius, Gesneriaceae) based on the habit, leaves arrangement, leaf-blade morphology, indumentum color in the young leaves and other vegetative structures, and inflorescence and calyx morphology described and depicted by Vellozo $(1829,1831)$. In this study, we discuss the similarities between both names and justify the inclusion of $P$. acaulis as a synonym of de $N$. primulifolius. Additionally, when investigating the identity of $N$. primulifolius, we also found another synonym (i.e., Oreocharis notha C.B.Clarke) for this name, with the type specimen erroneously cited as being from the Philippines.

\section{TAXONOMIC TREATMENT}

Napeanthus primulifolius (Raddi) Sandwith, Webbia 12(1): 332. 1956

Type: Brazil, [Rio de Janeiro]: [Mun. Magé], “[...] nei Boschi di Mandiocca vicino ai torrenti" [woods of Fazenda Mandiocca, close to streams], [1817-1818], G. Raddi s.n. (lectotype, first-step designated by Leeuwenberg $(1958$, p. 347$)$ as "holotype" and "isotype," secondstep designated here PI barcode PI006250! = K negative No. 2697; isolectotypes: FI barcode FI005344!, FI barcode FI005345!, PI barcode PI006251! = K negative No. 2696). Figures. 1, 2A.

(झ) Oxalis primulifolia Raddi [as "primulaefolia"], Mem. Mat. Fis. Soc. Ital. Sci. Modena, Pt. Mem. Fis. 18: 400. 1820
(三) Acetosella primulifolia (Raddi) Kuntze, Revis. Gen. Pl. 1: 93.1891

(=) Pedicularis acaulis Vell., Fl. Flumin.: 270. 1829 [1825, publ. 7 Sep-28 Nov 1829]; Fl. Flumin. Icon. 6: t. 107. 1831 [1827, publ. 29 Oct 1831], nom. illeg. non Pedicularis acaulis Scop. (1771), syn. nov.

Type: Brazil, [Rio de Janeiro], [Mun. Paraty], "[...] silvis maritimis Pharmacopolitanis," [1782-1790], [preserved specimen presumably not extant] (lectotype [icon] original parchment plate of Florae fluminensis in the Manuscript Section of the Biblioteca Nacional, digital object cat. No. mss1198655_111; later published in Vellozo, Fl. Flumin. Icon. 6: tab. 107, 1831). Fig. 2B.

(=) Napeanthus brasiliensis Gardner, London J. Bot. 2: 14. 1843

Type: [Brazil] Brasiliæ, [Rio de Janeiro] Provinciæ Rio de Janeiro, "in sylvis densis primævis in montibus vulgo Serra dos Organos," February 1838, G. Gardner 581 (lectotype designated by Leeuwenberg (1958, p. 348) as "holotype" K barcode K000601592 ex herb. Hook.!; isolectotypes BM barcode BM000992330 ex herb. Gardner!, BM barcode BM000992331 ex herb. Gardner!, CGE [cited by Leeuwenberg (1958)], E barcode E00155094!, FI barcode FI009832 ex herb. Webbianum!, G barcode G00365564!, G barcode G00365565 ex herb. Moric.! = F negative No. 26253!, K barcode K000601593 ex herb. Benth.! [annotated by Leeuwenberg (1958) as "isotype"], NY barcode NY00312996 ex herb. Meisner, comm. Schuttlenworth!, NY barcode NY00312997 ex herb. British Museum!, P barcode P00606336 ex herb. E. Drake!, W [cited by Leeuwenberg (1958)]).

(=) Oreocharis notha C.B.Clarke, Monogr. Phan. 5: 64. 1883 , syn. nov.

Type: Brazil, [probably Rio de Janeiro] Manille? [on the original label, referring to Manila, Philippines], S.loc. indicato, s.d., [probably A. Saint-Hilaire s.n.] (holotype P barcode P04060096 ex herb. Bory! = E photo barcode E00155095!).

\section{Description}

Terrestrial perennial herbs, $10-25 \mathrm{~cm}$ high. Stems short, 3-15 mm long, cylindrical, glabrous, rhizomatous. Leaves rosulate, grouped at the apex of the stem; leaf blade sessile, $5.0-23.0 \times 1.5-6.5 \mathrm{~cm}$, oblong-spathulate or oblanceolate, apex acute, base subcordate, margin slightly crenate-serrate, sinuate, glabrous adaxially, sparsely 


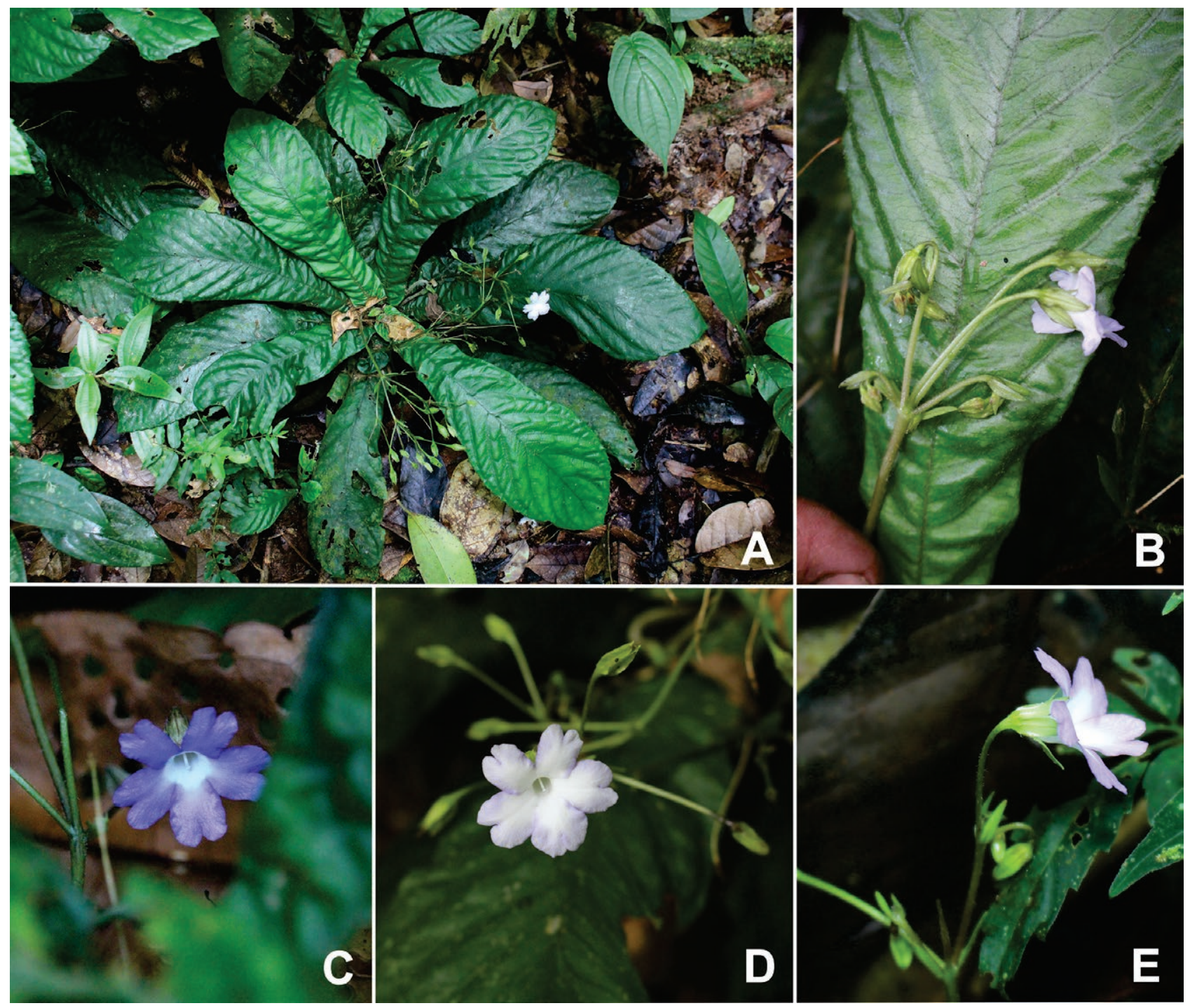

Figure 1. Napeanthus primulifolius (Raddi) Sandwith. A. Habit. B. Inflorescence detail. C. Flower at full anthesis. D. Older flower. E. Flower, lateral view showing the calyx lobes. Photographs taken by Nicco L. Faria.

pilose abaxially, trichomes concentrated on the veins, crass (papyraceous when dry); enervation with 6-9 pairs of secondary veins. Inflorescences simple, 4(-6)-flowered, or compound, with at least one of the lateral flowers replaced by a new peduncle; peduncles (or peduncles segments on compound inflorescences) $0.4-1.4 \mathrm{~cm}$ long, glabrescent; bracts $2,3.0-12.0 \times 1.0-4.0 \mathrm{~mm}$, linear, oblong or lanceolate, apex acute or acuminate, puberulous on both surfaces, green; pedicels $1.5-6.0 \mathrm{~cm}$ long, slender, glabrescent. Calyx campanulate, green; lobes 5, 7.0-15.0 $\times 3.0-5.0 \mathrm{~mm}$, equal, connate for $1 / 3$ to $1 / 2$ of their length, oblong, elliptic or lanceolate, spreading, inconspicuously veined, apex acuminate, margin entire, glabrous adaxially, puberulous abaxially, slightly fleshy, chartaceous when fresh, membranaceous when dry. Corolla early caducous, tubular, $10.0-15.0 \times 5.0-6.0 \mathrm{~mm}$, glabrous on both surfaces; tube $6.0-8.0 \mathrm{~mm}$ long, whitish; limb zygomorphic, spreading, lobes 5, 5.0-7.0 $\times 4.0-6.0 \mathrm{~mm}$, unequal, obovate, apex 2 -lobate, margin slightly crenate-serrate, sinuate, bluish or pale lilac, whitish at age. Stamens 4, included, didynamous; filaments $3.0-3.5 \mathrm{~mm}$ long, glabrous; anthers oblong-reniform, ca. $0.75 \mathrm{~mm}$ long; staminode 1, $0.8-1.0 \mathrm{~mm}$ long, glabrous. Ovary ovoid, glabrous; style 3.8-5.0 mm long, erect, glabrous; stigma obscurely 2-lobed; disk absent. Capsule 4.0-6.0 mm long, apiculate, 2 -valved, loculicidal; valves glabrous; accrescent calyx erect, enlarged, becoming thicker, conspicuously veined. Seeds ellipsoid, brown, shining. 

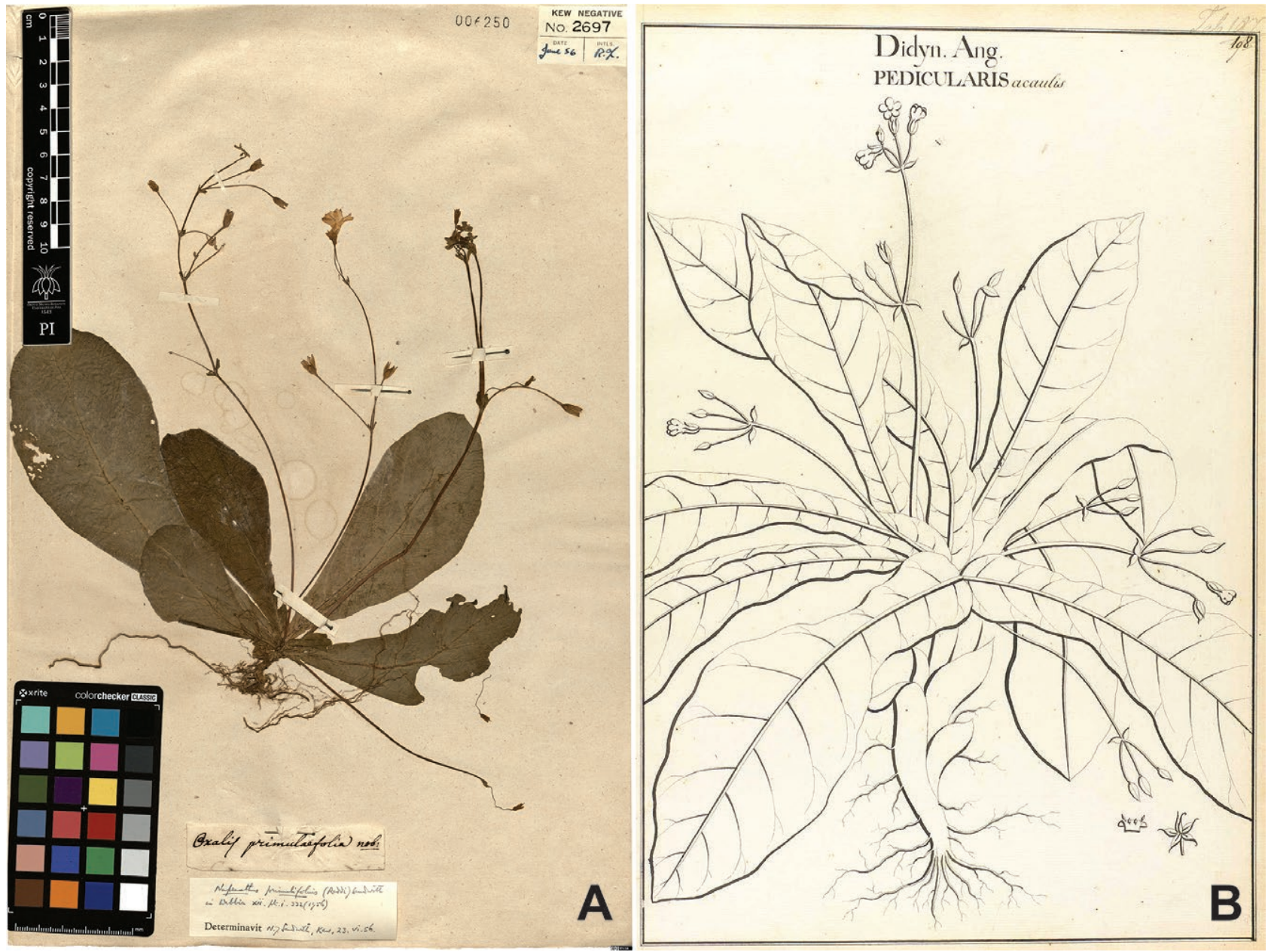

Figure 2. Napeanthus primulifolius (Raddi) Sandwith and its synonym Pedicularis acaulis Vell. A. The lectotype of Oxalis primulifolia Raddi, the basionym of N. primulifolius, at PI (barcode PI006250). Photograph courtesy of the Herbarium Horti Botanici Pisani (PI), Università di Pisa, reproduced with permission. B. The lectotype of Pedicularis acaulis from Biblioteca Nacional.

\section{Iconography}

Vellozo (1831, vol. 6: tab. 107), as Pedicularis acaulis Vell.; Hoehne (1970: tab. 189 and tab. 190), as Napeanthus brasiliensis Gardner; Chautems (2003: figure J, plate 1); Hinoshita et al. (2018: figure 1d-h).

\section{Distribution and habitat}

Napeanthus primulifolius is endemic to eastern Brazilian Atlantic Forest understories, especially on steep banks near streams where plants are rooted in earth among rocks. It was recorded in southern Bahia and in Serra do Mar Mountain Range (from Rio de Janeiro to northeastern Paraná).

\section{Specimens examined}

BRAZIL: Bahia: Mun. Arataca, Serra das Lontras, 12 February 2005 (fl, fr), J.G. Jardim et al. 4375
(CEPEC, NY, RB); ibidem, RPPN Caminho das Pedras, 22 July 2005 (fr), J.G.Jardim et al. 4726 (CEPEC); ibidem, Serra do Peito de Moça, 12 October 2005 (fr), A.M.A.Amorim et al. 5283 (CEPEC); ibidem, Serra do Peito de Moça, 14 April 2006 (fr), A.M.A.Amorim et al. 5781 (CEPEC); ibidem, Serra das Lontras, 29 April 2006 (fl, fr), A.M.A.Amorim et al. 5978 (CEPEC); ibidem, 21 January 2007 (fl, fr), R.A.X. Borges et al. 596 (CEPEC, NY); Mun. Buerarema, rod. São José da Vitória - Una, 12 May 1999 (fr), A.M.A.Amorim et al. 3065 (CEPEC, NY); Mun. Camacã, 21 January 1971 (fl, fr), T.S.Santos 1384 (CEPEC, US); ibidem, RPPN Serra Bonita, 2 February 2005 (fr), A.M.A. Amorim et al. 4770 (CEPEC, NY); ibidem, 29 October 2005 (fr), A.M.A.Amorim et al. 5427 (CEPEC); ibidem, 4 December 2007 (fl), M.M.M.Lopes et al. 1557 (CEPEC); Mun. Santa Luzia [= Mun. Camacã], Serra da Onça, 21 November 1996 (fl, fr), W.W.Thomas et al. 11382 (CEPEC); Mun. Una, 
Serra dos Quatis, 21 February 1986 (fr), T.S.Santos \& E.J.Judziewicz 4103 (CEPEC); ibidem, Serra Javi, 10 March 1986 (fr), T.S.Santos et al. 4226 (CEPEC, US). Paraná: Mun. Guaraqueçaba, Rio do Costa, 4 February 1971 (fr), G.Hatschbach 26267 (MBM, MO); ibidem, Salto Morato, 15 November 1993 (fl), G.Hatschbach \& J.M. Silva 59775 (MBM); ibidem, Morro do Bronze, 12 February 2002 (fl), J. Carneiro 1309 (MBM). Rio de Janeiro: S. loc. indicato, s.d. (fl), Glaziou 1075 (P); S.loc. indicato, 1821 (fl), Langsdorff s.n. (P barcode P03509121 ex herb. Richard); [Mun. Duque de Caxias], estrada Rio - Petropolis, 5 May 1972 (fl), D.Sucre \& T.Soderstron 9095 (RB); ibidem, Xerém, 22 March 1950 (fl, fr), Brade \& A.P. Duarte 20252 (RB); [Mun. Engenheiro Paulo de Frontin], Palmeiras, 13 January 1877 (fl), Glaziou 8835 (P - 2 sheets); Mun. Guapimirim, Granja Monte Olivete, 18 January 1995 (fl, fr), J.M.A.Braga et al. 1709 (RB), ibidem, Estrada das Andorinhas, 20 December 1995 (fr), J.A.LiraNeto et al. 189 (RB); Mun. Lídice, estrada Angra dos Reis - Lídice, 16 March 1978 (fr), V.F. Ferreira et al. 326 (RB); [Mun. Magé], [Fazenda] Madiocca, s.d., Riedel s.n. (LE, NY); ibidem, [...] prés Mandioca, 1816-1821 (fl), A.Saint-Hilaire s.n. (P barcode P03509114); ibidem, Serra dos Órgãos, 16 July 2017 (fr), J.M.A.Braga 17-042 (RB); Mun. Mangaratiba, Reserva Ecológica Rio das Pedras, 30 November 1996 (fl, fr), M.G.Bovini et al. 1104 (RB); ibidem, 9 December 1997 (fl, fr), R.C.Lopes et al. 86 (RB); ibidem, 16 March 2001 (fr), T.C.C.Lopes et al. 11 (RB); [Mun. Nova Friburgo], [Macaé de Cima] Alto Macahé, 15 June 1891 (fl), Glaziou 18412 (P, R); ibidem, 30 November 1891 (fl), Glaziou 19745 (P); [Mun. Nova Iguaçu], Serra do Tinguá, 11 February 1943 (fl, fr), F.Guerra s.n. (RB 47949); ibidem, Reserva Biológica do Tinguá, 17 January 2002 (fl), M.G.Bovini et al. 2143 (RB); ibidem, 22 October 2002 (fl), L.C.Giordano et al. 2585 (RB); Mun. Paraty, estrada Paraty - Cunha, 19 June 1978 (fr), G.Martinelli 4652 (RB); ibidem, Fazenda São Roque, 2 August 1988 (fr), M.C. Marques 72 (RB); ibidem, divisa dos estados Rio de Janeiro - São Paulo, 12 April 1991 (fr), L.S.Sarahyba et al. 812 (RB); ibidem, Patrimônio, 7 July 1992 (fr), L.C. Giordano et al. 1478 (RB); ibidem, Laranjeiras, 8 December 1993 (fr), T.Konno et al. 388 (RB); ibidem, Morro do Corisco, 8 March 1994 (fr), C.Duarte 21 (RB); ibidem, Apa-Cairuçú, 12 February 2003 (fr), M.G.Bovini \& M.Nadruz 2259 (RB); Mun. Petrópolis, Serra da Estrella, 16 June 1937 (st), J.G.Kuhlmann 123 (RB); Mun. São Fidélis, Poço Parado, 11 May 2012 (fr), M.Perret et al. 73 (VIES); [Mun. Teresópolis], Serra dos Órgãos, 10 December 1948 (fl), A.P.Duarte \& E.Pereira S.n. (RB 65302). São Paulo: Mun. Cunha, Parati - Cunha, 1 March 1984 (fl, fr), A.Chautems \& G.Martinelli 123 (US); Mun. Peruíbe,
Estação Ecológica Juréia-Itatins, 29 May 1996 (fr), L.P.Queiroz \& R.Belinello 4526 (HUEFS, SP); [Mun.] Santos, May 1875 (fr), Mosén 3789 (P ex herb. Glaz.); Mun. São Miguel Arcanjo, Parque Estadual Carlos Botelho, 20 April 2002 (fr), S.Bortoleto et al. 49 (ESA); ibidem, 8 December 2004 (st), A.O. Araujo 470 (ESA); Mun. São Sebastião, Parque Estadual da Serra do Mar, 20 April 2000 (fr), J.P.Souza et al. 3312 (ESA, MBM, SPF, UEC); Mun. Sete Barras, Parque Estadual de Carlos Botelho, 21 April 2002 (fr), R.Farias et al. 655B (ESA); Mun. Ubatuba, 1987 (fr), Edna (SUDELPA) s.n. (SPF 67679); ibidem, Parque Estadual da Serra do Mar, 15 January 1990 (fl), F.C.P.Garcia et al. 549 (ESA, IAC); ibidem, Picinguaba, 13 November 1990 (fl, fr), R.Maquete et al. 287 (IBGE, HRB, RB); ibidem, 2 December 1993 (fl), L.Rossi \& G.L.Esteves 1373 (SP, PMSP); ibidem, Estação Experimental do IAC, 17 November 1997 (fl), C.Kameyama et al. 113 (SPF); ibidem, Parque Estadual da Serra do Mar, 21 January 2001 (fl), P.Fiaschi \& A.Lobão 583 (SPF); ibidem, Picinguaba, 29 May 2014 (fl, fr), G.Colletta et al. 1707 (ESA); 29 May 2014 (fl), G.Colletta et al. 1708 (ESA); ibidem, 29 May 2014 (fl), G.Colletta et al. 1719 (ESA).

\section{Taxonomic and nomenclatural notes}

Vellozo (1829) described four species under Pedicularis L. (currently placed in Orobanchaceae) in his "Florae fluminensis" following the Linnaean arrangement "Didynamia, Angiospermia." Three of them corresponded to species of Acanthaceae, and one of them, Pedicularis acaulis Vell., which was annotated by Vellozo (1829) as of doubtful placement and possibly belonging to a different genus, does not. Pedicularis acaulis Vell. is a later homonym of $P$. acaulis Scop., an accepted name in Orobanchaceae for an alpine species from the Italian Alps to the northwestern mountains of the Balkan Peninsula (Mayer 1972). Since the description of $P$. acaulis Vell., this name has never been mentioned in any taxonomic treatment for Brazilian Lamiales and remained forgotten until this moment (pers. observ.). However, when we analyzed the original description (Vellozo 1829) and the later published original plate (Vellozo 1830) hosted at Biblioteca Nacional [National Library of Brazil] (Fig. 1B), we realized that some morphological characters, i.e., rosette habit, acaulescent stems, sessile leaves, cymose inflorescence simple or compound (with at least one of the lateral flowers replaced by a new peduncle), and the calyx lobes overlapping in the margin, matched those from the small gesneriad genus Napeanthus. Of the only two Napeanthus species in eastern Brazil, i.e., N. primulifolius, which occurs from Bahia to northeastern Paraná, and Napeanthus reitzii (L.B.Sm.) B.L.Burtt ex Leeuwenb., 


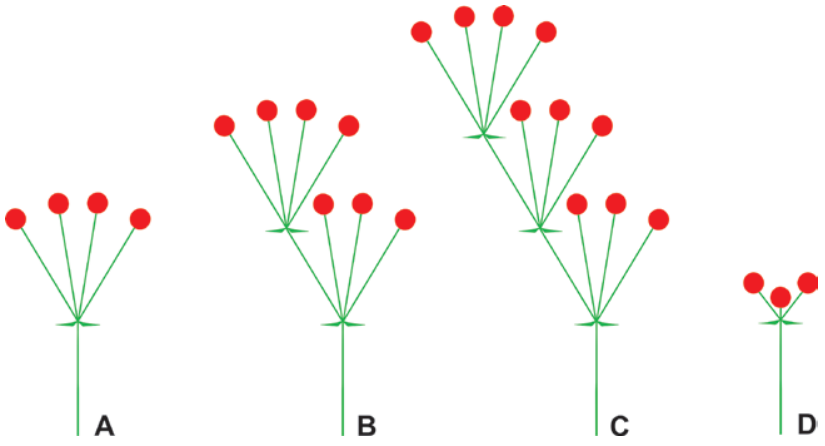

Figure 3. Inflorescences schemes of the two species of Napeanthus Gardner from Eastern Brazil. A-C. Napeanthus primulifolius (Raddi) Sandwith. D. Napeanthis reitzii (L.B.Sm.) Burtt ex Leeuwenb.

from Paraná and Santa Catarina], $P$. acaulis Vell. is conspecific with $N$. primulifolius, due to their rosette habit, acaulescent, pseudoverticillate leaves grouped at the stem apex, cymose inflorescences simple (often 4-flowered) or compound (with at least one of the lateral flowers replaced by a new peduncle) (Fig. 3A-C), flowers with long pedicels, and calyx lobes elliptical. Napeanthus reitzii is a herb with elongated stems, leaves distributed along the stem (with relatively short internodes), inflorescence cymose simple, 3-flowered (dichasium) (Fig. 3D), flowers with short pedicels, and calyx lobes trullate. Based on these morphological characters and geographic distribution, we propose the synonymy of $P$. acaulis Vell. under N. primulifolius. Furthermore, because there are no preserved specimens of Vellozo's names published in "Florae fluminensis" (see Lima 1995) and the illustrations (i.e., Vellozo 1831) were published after the protologue (i.e., Vellozo 1829) and are not considered part of the author's original material, in accordance with the Art. 9.4 and related of the International Code of Nomenclature for algae, fungi, and plants (Shenzhen Code) - ICN (Turland et al. 2018), we chose Vellozo's original plate as the lectotype.

Leeuwenberg (1958) referred to G. Raddi's specimens deposited at PI herbarium only as a "holotype" and "isotype," without any reference to the herbarium catalog number or even without any explicit indication in the sheets. Thus, we chose one of these specimens as a second-step lectotype, according to Art. 8.1 and 9.17 of the ICN (Turland et al. 2018).

When Clarke (1883) described Oreocharis notha, he was unsure of where this specimen was collected (possibly from Manila, Philippines) and the generic placement of this species, indicated in the protologue with a question mark. This author also pointed out that the long calyx and ovoid ovary in this species were different from other Oreocharis Benth. In fact, the calyx with long lobes accrescent in fruit is not found in any known species of Oreocharis s.str., not even in genera recently synonymized by Möller et al. (2011), which had calyx lobes shorter than the corolla. On the label of the specimen studied by Clarke (1883), housed at P herbarium, there is the following handwriting, possibly written after this author: "Napeanthus, ex h. Bory, A.S.-H. [August Saint-Hilaire], Brasilia!!" It is likely to be a duplicate of a gathering of A. Saint-Hilaire incorporated into Bory's collection for being an endemic species to eastern Brazil and unlikely cultivated as ornamental in the Philippines. Also, the Napeanthus specimen in the Saint-Hilaire collection and the type of Oreocharis notha in Bory's collection, both at $\mathrm{P}$, show inscriptions with the same handwriting.

\section{ACKNOWLEDGEMENTS}

We are incredibly grateful to the staff from PI herbarium, especially Dr. Francesco Roma-Marzio, for allowing us to use the lectotype image of Oxalis primulifolia Raddi in this paper; to Alain Chautems for his comments and suggestions that improved our work and for allowing us some bibliographies; to our friend Nicco Lopes Faria for kindly allowing us to use his photographs of Napeanthus primulifolius (Raddi) Sandwith; and to Scientifik Ltda. for reviewing the English language.

\section{REFERENCES}

Chautems A. 1991. A família Gesneriaceae na região cacaueira da Bahia, Brasil. Revista Brasil Bot. 14: 51-59.

Chautems A. 2003. Napeanthus Gardn.; p. 81-82. In: Gesneriaceae. In: Chautems A, coordinator. In: Wanderley MGL, Shepherd GJ, Giulietti AM, Melhem TS, Kirizawa M, editors. Flora fanerogâmica do Estado de São Paulo,vol. 3. São Paulo: FAPESP/RiMa; p. 75-103. https://www.infraestruturameioambiente. sp.gov.br/institutodebotanica/wp-content/uploads/ sites/235/2016/06/FFESP-Volume-III_06_24.pdf

Feuillet C, Skog LE. 2002. Novae Gesneriaceae Neotropicarum XII. New Species of Gesneriaceae from the Guianas. Brittonia. 54(4): 352-361. https://doi.org/10.1663/0007196X(2003)54[352:NGNXNS]2.0.CO;2

Gardner G. 1843. Descriptions of four new genera of plants from the Organ Mountains. London J. Bot. 2: 9-15.

Hoehne FC. 1970. Iconografia das Gesneriáceas do Brasil. São Paulo: Secretaria da Agricultura/Instituto de Botânica. 
Lima HC. 1995. Leguminosas da Flora fluminensis J.M. da C. Vellozo - Lista atualizada das espécies arbóreas. Acta Bot Bras. 9(1): 123-146. https://doi. org/10.1590/S0102-33061995000100006

Hinoshita LKR, Araújo AOA, Goldenberg R. 2018. Os gêneros Besleria, Codonanthe, Gloxinia, Napeanthus, Nematanthus e Seemannia (Gesneriaceae) no estado do Paraná. Rodriguésia. 69(2): 631-647. https://doi. org/10.1590/2175-7860201869226

Leeuwenberg AJM. 1958. Revision of Napeanthus; p. 340354. In: The Gesneriaceae of Guiana. Acta Bot Neerl. 7: 291-444. https://doi.org/10.1111/j.1438-8677.1958. tb00624.x

Leeuwenberg AJM. 1971. Notes on American Gesneriaceae VI. A new species of Napeanthus Gardn. Acta Bot Neerl. 20(3): 367-369. https://doi.org/10.1111/j.1438-8677.1971. tb00719.x

Luna JA, Richardson JE, Nishii K, Clark JL, Möller M. 2019. The family placement of Cyrtandromoea. Systematic Botany 44(3): 616-630. https://doi.org/10.160 0/036364419X15620113920653

Mayer E. 1972. Pedicularis L. In: Tutin TG, Heywood VH, Burges NA, Moore DM, Valentine DH, Walters SM, Webb DA, editors. Flora Europaea, vol. 3 (Diapensiaceae to Myoporaceae). Cambridge, UK: Cambridge University Press; p. 269-276.

Möller M, Middleton D, Nishii K, Wei YG, Sontag S, Weber A. 2011. A new delineation for Oreocharis incorporating an additional ten genera of Chinese Gesneriaceae. Phytotaxa. 23: 1-36. https://doi.org/10.11646/phytotaxa.23.1.1

Möller M, Clark JL. 2013. The state of molecular studies in the family Gesneriaceae: A review. Selbyana. 31 (2): 95-125. https://journals.flvc.org/selbyana/article/ view/123017

Ogutcen E, Christe C, Nishii K, Salamin N, Möller M, Perret M. 2021. Phylogenomics of Gesneriaceae using targeted capture of nuclear genes. Molec Phylogenet Evol. 157: 107068. https://doi.org/10.1016/j. ympev.2021.107068

Raddi G. 1820. Quaranta piante nuove del Brasile raccolte e descritte da Giuseppe Raddi. Atti della Società Italiana delle Scienze [in Modena]. 18: 1-35.

Sandwith NY. 1956. The identity of Oxalis primulaefolia Raddi. Webbia. 12(1): 331-333. https://doi.org/10.108 $0 / 00837792.1956 .10669664$

Skog LE. 1974. New Peruvian Gesneriaceae. Phytologia. 28(3): 233-240.

Smith JF. 2000. A phylogenetic analysis of tribes Beslerieae and Napeantheae (Gesneriaceae) and evolution of fruit types: Parsimony and Maximum Likelihood Analyses of $n d h F$ sequenc- es. Systematic Botany 25(1): 72-81. https://doi. org/10.2307/2666674

Turland NJ, Wiersema JH, Barrie FR, Greuter W, Hawksworth DL, Herendeen PS, Knapp S, Kusber W-H, Li D-H, Marhold K, May TW, McNeill J, Monro AM, Prado J, Price MJ, Smith GF [editors]. 2018. International Code of Nomenclature for algae, fungi and plants (Shenzhen Code) adopted by the Nineteenth International Botanical Congress Shenzhen, China, July 2017. Glashütten: Koeltz Botanical Books. (Regnum Vegetabile 159). https://doi.org/10.12705/ Code. 2018

Vellozo JMC. [1825] 1829. Floræ fluminensis [...]. Flumine Januario [Rio de Janeiro]: Typographia Nationali. https://doi.org/10.5962/bhl.title.745

Vellozo JMC. [1827] 1831. Floræ fluminensis Icones [...], vol. 6. Parisiis [Paris]: Officina lithographica A. Senefelder. https://doi.org/10.5962/bhl.title.70380

Weber A. 2004. Gesneriaceae. In: Kubitzki K, editor. The Families and Genera of Vascular Plants, vol. 7 (Dicotyledons. Lamiales (except Acanthaceae including Avicenniaceae), Kadereit J, volume editor). Berlin: Springer; p. 63-158. https://doi.org/10.1007/9783-642-18617-2

Wiehler H. 1983. A synopsis of the Neotropical Gesneriaceae. Selbyana. 6(1/4): 1-129. https://journals.flvc. org/selbyana/article/view/123017 